lasting only a few weeks, and was licensed only a few years ago on the strength of results that gave no hint of the easy trips to which Kramer refers. (I would not be surprised if some passages evoked in cannabis users a sense of déjà vu.)

It certainly will not do to declare: "It is not addictive - patients do not crave Prozac, and there is no known withdrawal syndrome" (p. 311). The clear message of history is to beware of any explosive, mass demand for a psychoactive drug, and never to forget that patients don't crave so long as doctors readily prescribe. It is also worth noting that there is still profound confusion over the differences in meanings of 'dependence' and 'addiction', despite clarification from the World Health Organization 30 years ago. The Royal Colleges of Psychiatrists and General Practitioners still insist that "antidepressants are not addictive" and that people are "mistaken" in thinking they can cause dependence (RCP/RCGP Defeat Depression Campaign Release, 1992), despite evidence that most antidepressants (unlike cocaine) are associated with a withdrawal syndrome. This is why the British National Formulary recommends that when patients stop taking these drugs, "reduction in dosage should preferably be carried out gradually over a period of about four weeks".

What the Royal Colleges are really saying is that antidepressants have no great market street value and do not lead to overt drug-seeking behaviour. But this does not properly address the concern that both doctors and patients may misinterpret withdrawal symptoms as recrudescence of disease, and then see this as evidence of the effectiveness of the drug and of the need to continue treatment with it. This is what happened with the benzodiazepines, barbiturates and all the rest, and it led to dependence on a grand scale.

And the risk would be greater with drugs such as fluoxetine, which are only slowly cleared from the body. This means that withdrawal symptoms tend to peak long after the drug is stopped and therefore that the drug would be less likely to be identified as their cause. In any case, if one defines 'dependence' simply as 'druginduced drug consumption', one would never conclude from Kramer's evidence that fluoxetine is a drug that anyone might take or leave at will:

We lowered the dose of medicine, and two weeks later Julia called to say that bottom had fallen out: "I'm a witch again." She felt lousy - pessimistic, angry, demanding . and then she used the very words Tess had used: "I don't feel myself.". . . Julia resumed taking the higher dose of Prozac. Within two weeks, she felt somewhat better; after five weeks, she was "almost there again," with many more good days than bad. She said work had been torture on the lower dose of medicine [pp. 29-30].
Bearing in mind that "Prozac has not been systematically studied, in animals or humans, for its potential for abuse, tolerance, or physical dependence" (Physicians Desk Reference, 4th edn, 943-6 (Medical Economics, Oradell, New Jersey, 1993)), it would be folly not to undertake searching enquiries into how Prozac is used and misused and to what effect. Some users clearly do benefit, although in pre-marketing trials one in seven patients had to quit because of adverse effects, most commonly psychiatric (ibid.). The broad spectrum of these unwanted symptoms is worrying, with some people becoming badly agitated and hyped-up, and others brought right down; in extreme cases, manic psychoses and suicide have been mentioned as real risks. In a mass market there will certainly be many casualties and much more could be done to prevent them.

Then there are uncertainties about dosing. Noting that patients responded in the wide range of $5-80 \mathrm{mg}$ per day, the Swedish and Norwegian authorities in 1991 refused to give Prozac a licence - because it was supplied only in a $20-\mathrm{mg}$ size. Kramer has little to say about doses, and where he does he seems unduly relaxed:

[Gail] asked whether I could raise the dose of Prozac so she would feel comfortable applying for the post. I did not know whether a different dose would have a different effect, but I saw no reason not to try. She took extra Prozac, and she applied for the promotion. She was eventually turned down, but she was able to take the rebuff in stride [p.94].

Who knows, Prozac may turn out to be the triumph of benefit over risk. In the meantime, it might be safer to regard this book as an object lesson in how not to evaluate a drug, and as a dire if inadvertent warning that products such as Prozac threaten to consume us all. We must not forget that the greatest mistakes in medicine tend to be made not because doctors don't know enough, but when they behave as if they do.

Charles Medawar is at Social Audit Ltd, PO Box 111, London NW1 8XG, UK.

\title{
Ne'er the twain shall meet
}

\section{RyanJ. Huxtable}

The Billion Dollar Molecule: One Company's Quest for the Perfect Drug. By Barry Werth. Simon and Schuster: 1994. Pp. 445. \$25.

Music lessons in my high school usually consisted of chanting "R-H-Y-T-H-M spells rhythm" or "Every Good Boy Deserves Fruit". On the rare occasions we had actual music, it was always something in a minor key, such as the song 'Behold a giant am I, aloft here in my tower'. This song is emblematic of the traditional academic, renowned in his field, living a monkish existence above the temporalities of common humanity. But, as another song has it, the times they are a-changing. Knowledge in US universities is now valued not for such unquantifiable attributes as 'for its own sake' but for the market price it carries. Forget the leather elbow patches on the smoky jacket. In the bright new world of managed scholarship and technology-transfer offices, the leather is on the briefcase of the professor raising venture capital for his biotech company.

This is the story of the collusions and clashes between industrial and academic scientists involved in a small company's search for a better immunosuppressant. A drug that can dislocate the biological system that asserts identity, distinguishing 'me' from 'not-me', is a valued product in an alchemical world of organ transplants. Hearts, lungs, bits of brains and even complete viscera are, in the argot of the trade, harvested from one individual and incorporated into another. The surgery is straightforward. Transplantation, howev$\mathrm{er}$, is vitiated by tissue rejection in the recipient. The alkahest that dissolves identity between donor and recipient, allowing the transplant to remain unrecognized, is an immunosuppressant. One immunosuppressant, cyclosporin, was isolated from a fungus growing in the wastes of arctic Norway. Another, FK-506, came from a mountainside in Japan. Both have numerous side effects. But suppose you engineered a drug specifically for the receptor that these immunosuppressants act on...?

The classic way of developing a drug once was to go to nature. That gave us morphine, vincristine, digitalis and taxol. Then the Faustian hubris of our species led us to think that whatever nature could do, we could do better. So we synthesized thousands of compounds more or less at random and tested them for drug activity. That gave us sulphonamides, INH, Salvarsan and propranolol. Then came Joshua Boger, founder of Vertex. His company would use a third, new way, of developing drugs: it would design them. Structure-based design would identify what a drug had to do and where it had to bind, and then the appropriate molecule could be custom designed. Line the balls up, tap gently with the cue and bingo! Illimitable largesse - the billion dollars of the book's title - would pour into the 
pockets of the company. Midas never had it so good. There is a bright new language for this brave new world, such as "God mode" to mean total control, as in "we're in God mode".

Boger assembled a team of bright minds from Harvard and Merck and elsewhere. But the company was snookered before sinking the 8 ball. The coalition of magicians coaxed from academia or seduced from industry turned out to be as illusory as the glass walls enclosing Marcel Marceau. The academics go their own way. The betrayed parent companies fight back with their own research programmes. Vertex hides information from its academic consultants. The consultants hide information from the company. Harvard gets concerned that it's losing control over profitable technology. The company continues to haemorrhage money like a politician up for re-election. It is rescued temporarily by white knights with Japanese faces, in the form of the Chugai company. Apollo is transformed into Dionysis as Vertex swerves into tantrums, fights, sleepless nights, drunkenness and traffic accidents. Success of a sort, however, does come in the fourth act of the drama. But ironically it comes by the method Vertex set out to eschew; the serial synthesis of compound after compound, ringing the changes on the carillon of structure. The three-hundred-andsixty-seventh compound tested, V-367, has activity; here are the echoes of the Dengel's compound D-365 (verapamil) or Ehrlich's first success with the antispirochaetal compound 606 (Salvarsan).

Illusion is the motif of this story. It impresses by the amount of show rather than substance. From the molecules that exist on computer screens but not in test tubes, to the expectations of investors that correspond to no reality in the world of dimensions, to the negotiations with Chugai in Japan and Glaxo in England, this is a world in which honesty and straightforwardness seem as out of place as gonorrhoea in a nunnery. It is all flickering shadows in Plato's cave with no fire at the entrance. The only reality is the perception.

The book is up-to-date, covering events of barely a year ago. It is so up-to-date, in fact, that the fifth act, the resolution of the drama, is missing. The reader is left hanging like a car on an earthquakeshattered freeway. The storyline is not clear, and time, as befits the world behind the looking glass, does not adhere to chronology. The book, however, rattles along. During the unravelling of the story, the reader will learn a fair bit of the history of drug discovery and the rise of the pharmaceutical industry in this century. Many familiar names such as L. Pauling and R. B. Woodward make cameo appearances. Appropriate to our times, the story is an ambiguous one. Is it a story of success or failure? Or something in between? Is it a morality tale, and should "East is east, and west is west, And ne'er the twain shall meet" apply to academics and their journeyings to the industrial orient?

Ryan J. Huxtable is in the Department of Pharmacology, University of Arizona, Tucson, Arizona 85724, USA.

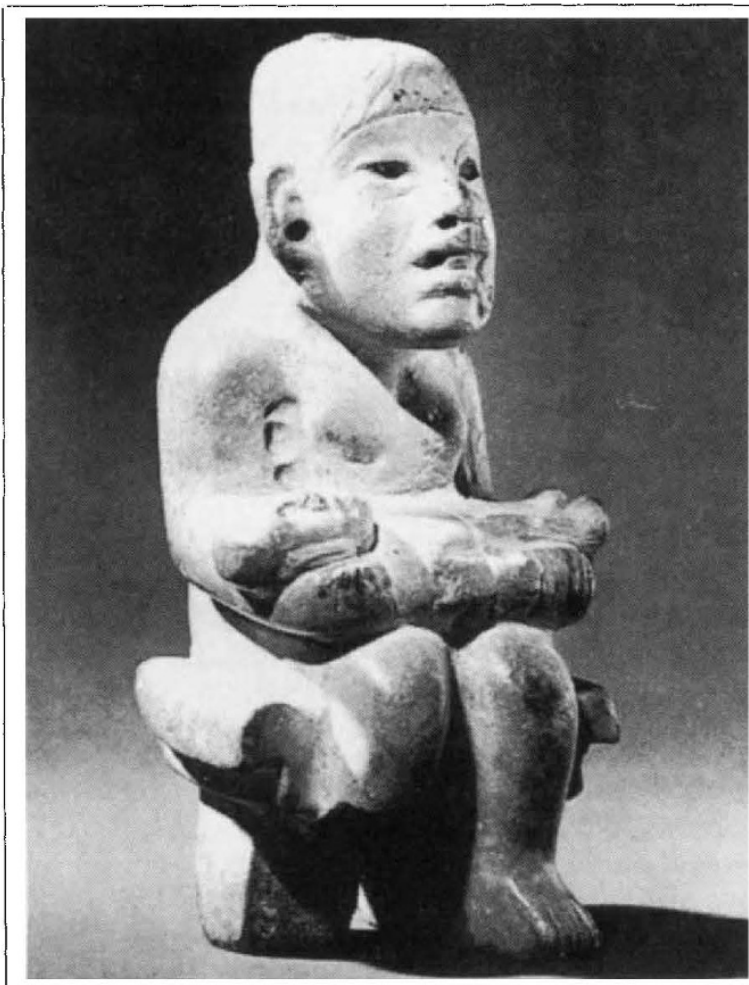

SMALL stone figure of a woman and child from the Oimec, the most ancient Mexican civilization (Middle Preclassic, 1200-400 8C; $11.4 \mathrm{~cm}$ ). The OImec style is typified by small jade sculptures and other objects that emphasize human infants with snarling, jaguar-like features. It takes its name from the 'Olmeca', the mysterious 'rubber people' described by Sahagún and his Aztec informants as inhabiting the jungle country of the Gulf coast, to which many of these artefacts can be traced. In fact, nothing is known about the originators of Olmec art. This photo appears in the fourth edition of Mexico by Michael D. Coe (Thames and Hudson, £8.95 (pbk)), widely hailed as the classic introduction to the region's ancient civilizations.

\section{Hidden enemies, foreign invaders}

\author{
W. F. Bynum
}

Silent Travelers: Germs, Genes, and the Immigrant Menace. By Alan M. Kraut. BasicBooks: 1994. Pp. 369. \$25.

Living in the Shadow of Death: Tuberculosis and the Social Experience of Illness in American History. By Sheila M. Rothman. BasicBooks: 1994. Pp. 319. \$25.

MY forebears crossed the Atlantic, probably from Holland, sometime before 1820 , when the family genealogy falls silent. Most of Alan Kraut's immigrants went to the New World later, and from less prosperous countries: Ireland, southern Italy, eastern Europe, the Far East. The great wave of immigration spanned the period from the Irish potato famine of the $1840 \mathrm{~s}$, through the pogroms in eastern Europe of the late nineteenth century, the continuing poverty of Asia and the Mediterranean basin, and the disruptions of the Great War. Most emigrants were poor, taking little with them but their ambitions, language, traditions, genes and germs. For most, the language was not English.

The Great Melting Pot theme in American history has often been recounted, though not before with Kraut's medical slant. Silent Travelers weaves together two stories - the medical inspection that greeted would-be Americans on arrival, and the health problems that faced those who were allowed in. His subtext is the increasing concern of those born in the United States with foreigners, fears which led to tough immigration laws in the 1920 s and made it difficult even during the Nazi period for refugees to count on the United States to become home ("the place where, when you have to go there, they have to take you in").

Periodical medical inspection of travellers and migrants has been around for a very long time, forming the administrative rationale for quarantine since the Middle Ages. It gradually became ritualized during the nineteenth century, and the depot on Ellis Island, New York, opened in 1894, was where millions of immigrants first encountered New World bureaucracy. Medical officers sought to identify those with dangerous or 'loathsome' diseases, the insane and 'idiots', and individuals thought likely to become a public charge. The rhetoric was pretty Draconian and Ellis Island figured prominently in the memories and memoirs of many who passed through. Nevertheless, the doctors made little impact on the immigration itself, never rejecting more than three per cent of those they examined. Despite the long list of conditions 